\title{
An Analysis of The Initial Profile of Students Critical Thinking Skills in Learning Circulator System at XI Grader of SMA N 1 Gondang Sragen
}

\author{
${ }^{1 \text { st }}$ Joko Suyamto, \\ Postgraduate of Science Education \\ Sebelas Maret University of \\ Surakarta \\ Surakarta, Indonesia
}

\author{
${ }^{2 n d}$ Muhammad Masykuri \\ Postgraduate of Science Education \\ Sebelas Maret University of \\ Surakarta \\ Surakarta, Indonesia
}

\author{
${ }^{3 r d}$ Sarwanto \\ Postgraduate of Science Education \\ Sebelas Maret University of \\ Surakarta \\ Surakarta, Indonesia \\ djokersuper38@gmail.com
}

\begin{abstract}
The critical thinking is an ability to think reflectively and reasonably in making decision. The research is a qualitative-descriptive research with an objective to analyze students` critical thinking in learning circulatory system. The samples were taken clustered-randomly. There were 36 science and math XI grader students as the samples in SMA N 1 Gondang Sragen. The instruments of critical thinking skills used essay (6 questions) that was developed from Fascione critical skill aspects. From the data analysis it revealed that $43,83 \%$ of students were in low category. The percentage of interpretation aspect was in low category $(38,33 \%)$. The analysis aspect was also in low category $(43,20 \%)$. The evaluation aspect was also in low category $(32,75 \%)$. The inference aspect was in low category $(57,57) \%$. The explanation aspect was in low $(26,40 \%)$. Meanwhile, the percentage of self-regulation aspect was in average $(64,73 \%)$. From the research, it showed that the students`ability to think critically was in low category and the teacher should make an effort to improve learning process so that the students` critical thinking skills will increase.
\end{abstract}

Keywords- Initial Skills, Critical Thinking Skills, Circulatory System.

\section{INTRODUCTION}

No one can guarantee that the information on electronoc media, social media or print media is definitely corect. We have to evaluatethe information we get. The ability in evaluating and making decision to use that information correctly demands critical thingking skills (Potter, 2010). There skills must be matered by an individu since she is in senior high school, because these skills are assencial in individual development in evaluating and deciding the conclution of information. Facione (2011) statet that the ability to think critical refers to the ability that it crucial to their future lives. The reason is that someone's critical think skills may lead to decide correctly.

Individu critical think skills will impact possitively toward individual skills in deciding wheather an information is valid or not, responsible sourced or not, so that they can decide they will accept the information or not. Thinking critically is a basic or intelectual capital that is very principal for everyone and is a fundamental part ofhuman maturity. There for developing critical thinking skills is very important for all student in very ladder. Curiculum that make teachers focus only to finish the material and the low of teachers understanding of teachersmethod that improve students' critical think skills, are two main factors that make the skills do not develop. The National Council For Exelent in Critical Thinking in Theodurus .M Tuanakotta (2011) stated that critical thinking skills refers to the disciplin process thinking that is sourced from ability and activity to make concept, aplicate, analyze, synthesize, and evaluate the renehed information based on reflective observation or communication and also thredtment. Facione (2011) stated than critical thinking skills includes six aspects, they one interpretation, analysis, evaluation, inference explanation, and self regulation. They can be develop into some subskills in table 1 .

Table. 1. Indicator critical thinking skills modified

\begin{tabular}{|c|c|}
\hline Indicators & Subskills \\
\hline Interpretation & $\begin{array}{l}\text { Able to mentory what is questioned } \\
\text { clearly and correctly }\end{array}$ \\
\hline Analysis & $\begin{array}{l}\text { Able to write whta must to do ins } \\
\text { answering questions }\end{array}$ \\
\hline Evaluation & Able to write the questions solving \\
\hline Inference & $\begin{array}{l}\text { Able to conclude the questions } \\
\text { logically }\end{array}$ \\
\hline Explanation & $\begin{array}{l}\text { a. able to write the finsl result } \\
\text { b. able to give reson about the } \\
\text { conclution }\end{array}$ \\
\hline Self Regu & Able to review the answer \\
\hline
\end{tabular}

Human Development Index (HDI) Indonesia in 2006 was in 108 from 177 countryes (UNDP,2006). It showed that the quality of human resource was low it means that the education system in Indonesia is weal. As a results, human resource produced was uncontident generation low ability to work, less skilled, and low characters it is not surprised it the quality of human resource in HDI was for away under Malaysia, Thailand, Filiphina and mainly Singapura that is in High Human Development (UNDP,2006). Based on the data from 
PISA in 2000, Indonesia was in 38 from 41 countries. In 2006 Indonesia wa in 50 from 57 countries. In 2015 Indonesia was in 64 from 72 countries. The PISA measurement includes skills to form the problem, to get new knowledge, to explain to knowledge, to investigation on math and science.

Base on the observation on SMA N 1 Gondang Sragen, it showed that there were only few teaching learning process leaded to critical thinking process. The teacher learning process was convensionally centered on the teacher and not oriented in critical thinking. The teacher had not optimized the teaching learning process that was oriented on scinence process. The teacher domanded students to listen to the materials and there was no change for students to deliver their opinion. As a result, the student tended to be passive and were not used to think critically. From the observation is showed that the students were no used to learn used investigative process. From the reasons above, the teacher should arrange teaching learning process that can improve students critical thinking skills. Internal factors impact these skills, too one of them is inicial skills.

Puwandari, et.al.(in Mahendra, 2015) stated that initial skill refers to knowledge, skills, and ability mastered by students to study a new task. It is the precondition needes to enter the next task. It impacts how long students understanding the subject. Students with high initial skill will not face any difficulty in understanding the subject, meanwhile the students with low skills will difficulty and be hard to think critically.

A critical thinker is able to analyze and evaluate every information they receive. As stated by Duron, et.al. (2006) critical thinkers are able to analyze and evaluate information, bring up questions and vital problems, arrange them clearly collet and decide the relevn information using abstract ideas, open minded, and communicate it effetively.

In facing problems student can use Facione steps. The step of over coming the problem the problem by thinking critically is identifying the problems and set priorities; deepen understanding and determine relevant information; enumerate options and anticipate consequence; asses the situation and make a preminary decision; scrutinize the process the process and correct as nedded.

The objection at this research is to analyze students critical thinking skills in SMA N 1 Gondang Sragen. After the research is revealed, the teachers is hoped to be motivated to arrange the better learning process, so that students critical thinking skilss will improve.

\section{RESEARCH METHODOLOGY}

This research was taken in SMA N 1 Gondang Sragen using randomly 36 students as sample. Sugiyono (2015) stated

That random sampling is a technique that all members have the same change to be taken. This is a descriptive qualitative research that is aimed to understand the phenomenon in the subject of the research (Arikunto, 2000). The teqnique of collecting data used observation sheet and essey developed from critical thinking skills by Facione (2011) include six aspects; (1) interpretation; (2) analysis; (3) evaluation; (4) inference; (5) explanation; (6) self regulation.

The procentage are crunted as folows :

$$
\text { The Procentage }=\frac{\text { Sum of score total }}{\text { maximal score }} \text { X (Arikunto, 2015) }
$$

Presentage score of Critical thinking skill got from the calculation then categorized appropriate table 2 .

Table. 2. Category of Critical thinking skill presentage

\begin{tabular}{|c|c|}
\hline Interpretation $(\boldsymbol{\%})$ & Category \\
\hline $8,25<\mathrm{X} \leq 100$ & Very High \\
\hline $71,50<\mathrm{X} \leq 81,25$ & High \\
\hline $62,50<\mathrm{X} \leq 71,50$ & Medium \\
\hline $43,75<\mathrm{X} \leq 62,50$ & Low \\
\hline $0<\mathrm{X} \leq 43,75$ & Very Low \\
\hline
\end{tabular}

(Karim, 2015)

\section{RESULT AND DISCUSSION}

The students of SMA N 1 Gondang Sragen critical thinking skills ware low. It can be seen from the average procentage that was only $42,83 \%$. The low of students skills were caused by the applied by the school. The teachers still used convensional method, including speech method (centered on the teachers) so that it could not lead the students to try to think critically. As the same result by Pathonah (2014) stated that teacher dominated learning process, will lead to the students in remembeing, not improving thinking skills. It resulted in students class XI SMA N 1 Gondang Sragen skill was showed from tghe result of essay test as show on figure 1.

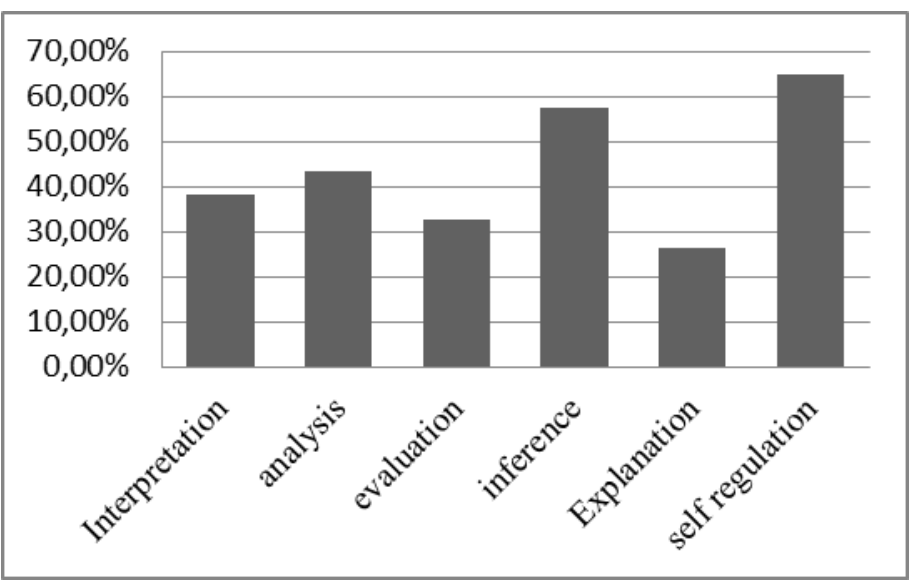

Figure 1. The precentage of students critical thinking 
Based on the figure 1 above it can be concluded that students critical thinking skills in SMA N 1 Gondang Sragen belongs to low category $(43,83 \%)$. Interpretation aspect was $38,33 \%$. Analysis aspect $43,20 \%$. Evaluation aspect $32,75 \%$. Inference aspect $57,57 \%$. Explanation aspect $26,40 \%$. Self regulation $64,73 \%$.

\section{Interpretation Aspect}

Interpretation refers to a skill to understand and explain the definition of situation, experience, incident, data, decision, convension, trust, rules, procedures and criteria. The indikator of interpretation is on question 1. There are data of self dairy experiences, student distribution of his indicator are shown on figure 2 .

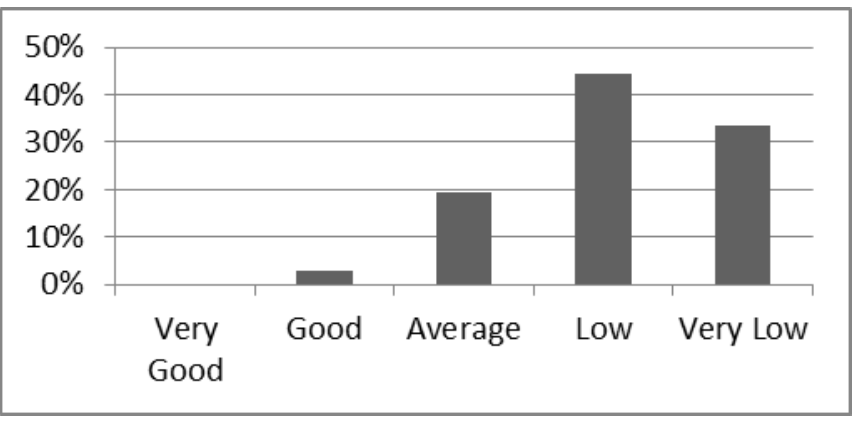

Figure. 2. Distribution interpretation aspect

From the figure 2 above, the average of student critical thinking in interpretation aspect is $38,33 \%$ ( low category). Student distribution in interpretation aspect is $13,33 \%$ on very low, $44,45 \%$ on low category, $19,45 \%$ on average category, $2,77 \%$ on good category, and $0 \%$ on very good category. Based on the student answers number 1, these were many student faced difficulties in analysing and evaluating correctly. It means that needs to improve students skill in categorizing the problems most students did not define based on the questions. The low overall average was caused by their low interest in observation process and problem solving. Their experience in observating can give students new information and they always remember it. As started by Sabri in Mustaqim (2013) studying is process at change. The experience can improve sstudent knowledge, skills, attitude and all aspect.

\section{Analysis aspect}

Analysis skill is students skill in starting the result of explanating the reason based on the evidence, concept, methodology, criterrology, and contex. The indicator of this aspect was in question number 2. Students distribution of the aspect is shown in figure 3 .

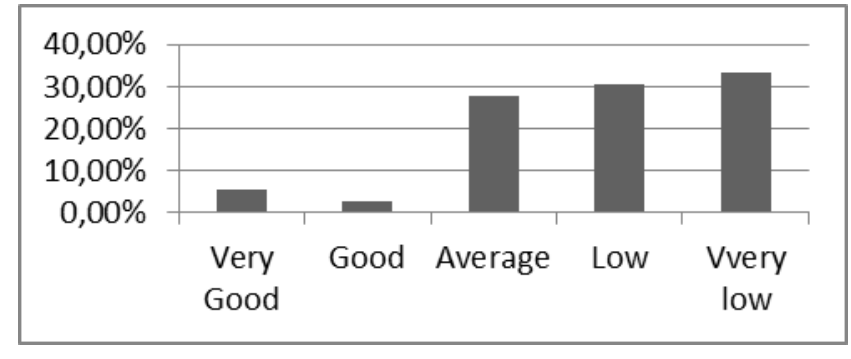

Figure. 3. Distribution Analysis Aspect

The figure 3 of students analysis indicator distribution based on the figure abaove it show that the precentage of students critical thinking skill in aspect analysis was $43,20 \%$ (in very low category). The distribution of students skill in analysis aspect was $33,34 \%$ in very low category, $30,56 \%$ in low category, $27,78 \%$ in average category, $2,77 \%$ in good category, $5,56 \%$ in very good category. From their answers, it showed that many students were not able to connect the concept using to answer the questions. The were same students who explained their answer incompletely about blood circulation. There for, teacher should make an efford to increse students' identification skills, linking concept and expressing them. Students who were not too active in grup discussion made them diffucult o analyze. As stated in Blomm Taxonomy, analysis thingking refers to number four step, after knowledge, understanding an appliction. It is impossible for sameone to think analytically without mastering three previons aspects. It is a need to improve students' analysis skill by accostuming students in including the concept.

\section{Evaluation Aspect}

Evaluation refers to a skill to examine statement used to deliver idea, perception, view, decision and opini. Evaluation indicator is in question number 3 . The percentage of students distribution is figure 4 .

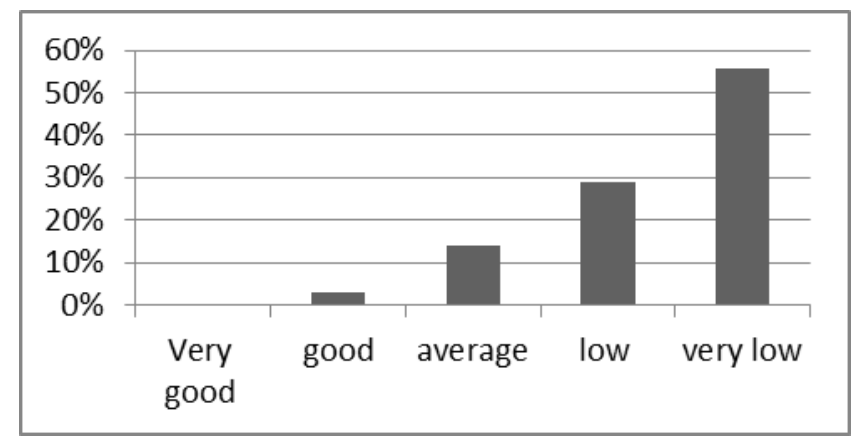

Figure. 4. Distribution evaluation aspect

Based on the figure 4 above, students' average mark in evaluation aspect was $32,75 \%$ in very low category. The distribution was $55,56 \%$ in very low category, $28,78 \%$ in low category, $13,89 \%$ in average category, $2,78 \%$ in good category, and $0 \%$ in very good category. From they asnwers, there are many students who are not able to finish the questions correctly. The teacher should guide them to 
interprate the fact and logic in the from of new discovery as objective information.

\section{Inverency Aspect}

Inverency refers to an ability identify or choose a reaseon to hypothesize and diagnose to consider what information nedded and decide concequency that must be taken from data, information, statement, princip, concept of opinion and soon. The indicator is stated in question number 4 . The distribution of inverency indicator can be seen on figure 5 .

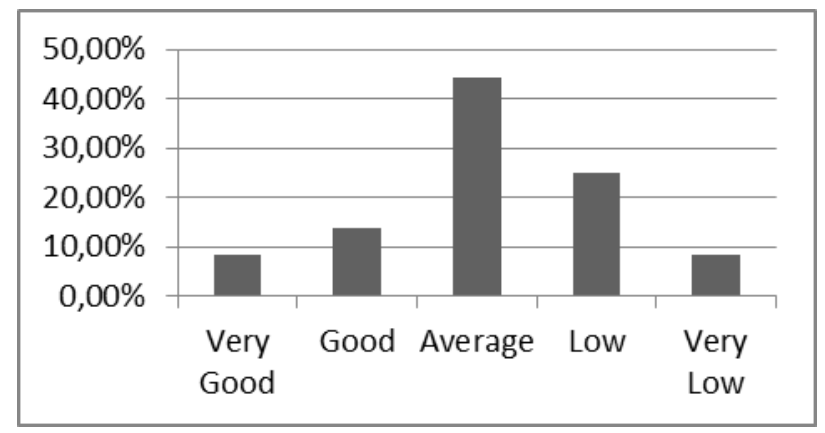

Figure. 5. Distribution analysis aspect

Based on the figure above, the percentage of inverence only indicator was $57,47 \%$ in low category. There were only few students belonged to exelent and good category. The distribution was $8,34 \%$ in very low category, $25 \%$ in low category, $44,45 \%$ in average category, $13,89 \%$ in good category, and $8,34 \%$ very good category.

It was caused by their inactivity in group discussion. Most students ignored the planning steps, so that they low score in inverency indicator. The teacher should guide the students inprove students' inverency skills.

\section{Explanation Aspect}

Explanation skill refers to skill that stated the thinking of explaning reason based on concept of concideration, evidence, methodology, criteriology, and context. This indicator is stated on question 5. The students' distribution can be seen on figure 6.

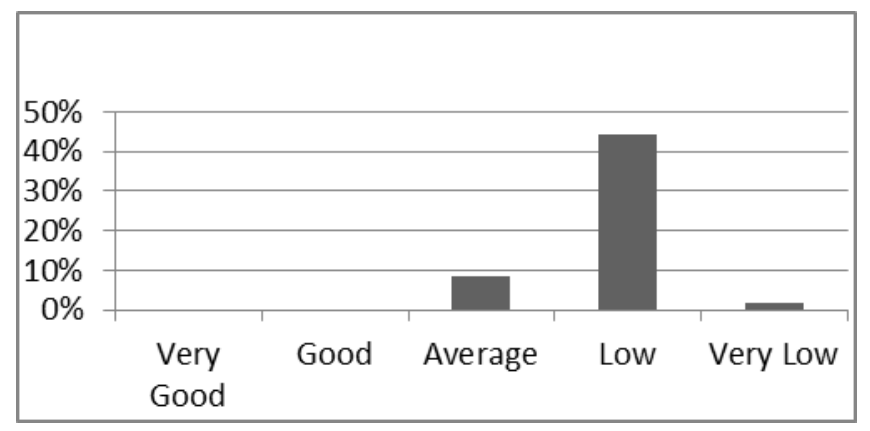

Figure. 6. Distribution explanation aspect

Figure 6 of explanation indicator distribution from the data above, it can be concluded that students' explanation skill was $26,40 \%$ in very low category. Most students was $1,94 \%$ in very low category. $44,45 \%$ in low category, $8,34 \%$ in average category, $0 \%$ in good category, and $0 \%$ in very good category. Most students was sufficent in explaining. They were not active to ask questions to teacher. It was coused by some students who explained the material about blood circulation incompletely. They were not used to explain conceptually and the result was not maximal.

\section{Self regulation aspect}

Self regulation refers to skill to manage in thingking some one will always recheck thair thingking to be revised, to get better decision. The indicator is stated on question number 6 . The students distribution can be seen on figure 7 .

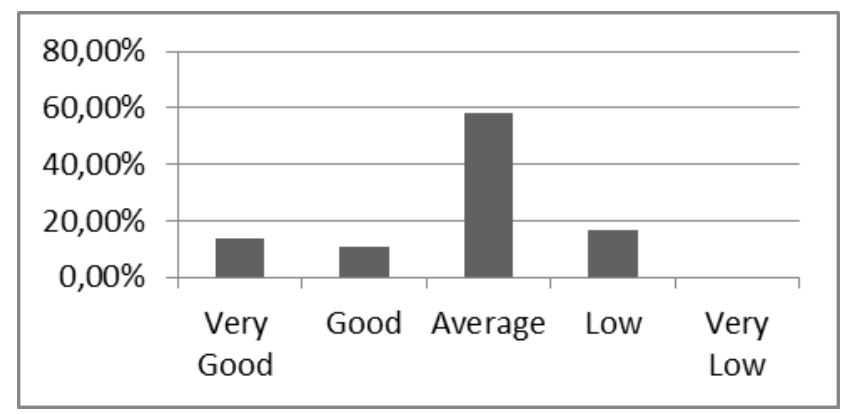

Figure. 7. Distribution self regulation aspect

Based on the figure 7 , the overange of students self regulation was $64,75 \%$ belonged to average category. By involving the students directly in learning process, it is hoped students more active and able to develop their thinking skill. However the result was in satifactory category. It was caused by their in confidence.

\section{CONCLUSIONS}

From the research and data analysis, it can be concluded that the ctitical thinking at studentsof SMA N 1 Gondang Sragenin biology subject especially blood circulation was in low category overall, that was $43,83 \%$. The precentage of interpretation aspect was $38,33 \%$ in low category, analysis aspect was $43,20 \%$ in low category, evaluation aspect was $32,75 \%$ in low category, inverency aspect was $57,57 \%$ in low category, explanation aspect was $26,40 \%$ in low category, and self regulation aspect was $64,73 \%$ in medium category. The result gives instrument to the teacher, student, and school, so that the teacher can present, activity using critical thinking skills.

\section{Acknowledgment}

Thanks to the graduate lecturer of the Science Education, Biology Education Program, Sebelas Maret University, who has guided the article writing and motivated the completion of this research. Thank a lot for the head master of SMAN 1 Gondang Sragen, who has given me permission to do this research. Thanks a lot for the students grade XI MIA SMA N 1 Gondang Sragen, who has help and contribute on this research. 


\section{References}

Arikunto. (2009). Dasar- Dasar Evaluasi Pendidikan. Jakarta : Bumi Aksara.

Duron, Robert, Barbara Limbach and Wendy Waugh. (2006). Critical Thinking Framework For Any Discipline. International Journal of Teaching and Learning in Higher Education, Volume 17, No 2, 160-166.

Facione, P. A. (2011). Critical Thinking: What It Is and Why It Counts. California: Measured Reasons LLC.

Fithriyah, dkk. (2016). " Analisis Kemampuan Berpikir Kritis Siswa Kelas Ix-D Smpn 17 Malang”. Proseding Konfrensi Nasional Penelitian Matematika dan Pembelajarannya. Universitas Muhammadiyah Surakarta

Karim, Normaya. (2015). Kemampuan Berpikir Kritis Siswa dalam Pembelajaran Matematika Dengan Menggunakan Model Jucama di Sekolah Menengah Pertama. Edumat jurnal Pendidikan Matematika, volume 3, No 1, April 2015. 92-104.

Mahendra, R., Murtafiah, W., Adamura, F. " Profil Penalaran Siswa Kelas X Sma Dalam Menyelesaikan Masalah Persamaan Kuadrat Ditinjau Dari Kamampuan Awal Siswa ". Jurnal Ilmiah Pendidikan. Vol. 4 No.1

Musfiqon, (2013). Pengembangan Media Dan Sumber Pembelajaran. Jakarta : PT. Prestasi Pustakarya

Patonah, S. (2014). Elemen Bernalar Tujuan Pada Pembelajaran Ipa Melalui Pendekatan Metakognitif Siswa. Jurnal pendidikan IPA Indonesia, 3 (2) . 128 133.

Pidarta. Made. (2000). Program Penyelenggaraan Akselerasi. Jakarta : Direktorat Pendidikan Luar Biasa Ditjen Dikdasmen Depdiknas.

PISA. (2006). Science Competencies for Tomorrow's World Volume 1- analysis. OECD.

Potter, Perry. (2010). Fundamental of Nursing : Concep, Proses and Practice. Edisi 7. Vol. 3. Jakarta : ECG.

Tuanakotta, Theodorus. M. 2011. Berpikir Kritis Dalam Auditing. Jakarta : Salemba empat.

United Nation Development Programme (UNDP). 2006. Human Development Report 2007/ 2008. New york : United Nations Development Programe. 